\title{
Study on Deformation Evolution Characteristics of Reverse-Dip Rock Slope under the Influence of Rainfall
}

\author{
Jiabing Zhang, ${ }^{1}$ Liangfu Xie $\mathbb{C D}^{1,2}$ Xuejun Liu, ${ }^{3}$ Yongjun Qin, ${ }^{1,2}$ and Liming $W u^{1}$ \\ ${ }^{1}$ College of Civil Engineering and Architecture, Xinjiang University, Urumqi 830046, China \\ ${ }^{2}$ Xinjiang Civil Engineering Technology Research Center, Urumqi 830046, China \\ ${ }^{3}$ Xinjiang Academy of Architectural Science (Limited Liability Company), Urumqi 830046, China \\ Correspondence should be addressed to Liangfu Xie; xieliangfu@xju.edu.cn
}

Received 3 September 2021; Accepted 25 October 2021; Published 6 December 2021

Academic Editor: Nan Zhang

Copyright ( 92021 Jiabing Zhang et al. This is an open access article distributed under the Creative Commons Attribution License, which permits unrestricted use, distribution, and reproduction in any medium, provided the original work is properly cited.

In Southwestern China, there exists deep river valleys and abundant rainfall, which leads to a large number of reverse-dip rock slopes. In order to investigate the evolution characteristics of toppling deformation of reverse-dip slope under the influence of rainfall, and a typical reverse-dip slope was taken as an engineering case. Firstly, the temporal and spatial evolution nephogram of toppling displacement under different rainfall was obtained based on the discrete surface displacement monitoring data of bank slope. Then, taking bank slope, gully buffer zone, and development degree of bank slope as development characteristics based on geological field survey, afterward, the evolution characteristics in different strong deformation zones were analyzed by superimposing the development characteristic partition and the spatial and temporal displacement nephogram. The results showed that the horizontal displacement mainly occurred on the right front and middle rear of the bank slope while large vertical displacement occurred on the middle of the bank slope under the influence of rainfall. As the rainfall increased to the maximum, the toppling deformation reached the peak, and vertical displacement was more sensitive to the rainfall than horizontal displacement. After the superposition, the largest strong deformation zone was located in the middle and rear part of the bank slope, which is characterized by medium and high slope and mature stage and $50 \mathrm{~m}$ gully buffer zone. This paper explores the deformation and failure process of reverse-dip rock slope considering the change of rainfall through real displacement monitoring data and focuses on the real deformation evolution law of each characteristic zone combined with different development characteristics partition.

\section{Introduction}

Toppling deformation is a kind of phenomenon that the reverse-dip rock mass bends and breaks to the free face under the coupling function of gravity and in situ stress. In the southwest of China, there exists deep river valleys and complex topographic and geological conditions, which leads to many high and steep reverse-dip rock slopes under the function of the uplift of Qinghai Tibet Plateau, and it is counted that about $33 \%$ of the slope deformation occur in the anti-inclined slope $[1,2]$. Scholars mainly qualitatively describe the toppling deformation and failure based on the actual cases [3-13]. Caine [14] surveyed the cliff collapse on the edge of Tasmania plateau and pointed out that this failure was caused by the toppling of rock stratum. Besides, some scholars classify rock slopes according to toppling failure types. Based on practical engineering cases, Goodman and Bray [15] categorized toppling failure into three types, including flexural toppling, blocky toppling, and blockflexural toppling. Nichol et al. [4] classified toppling failure into brittle fracture toppling and flexible bending toppling according to the hardness and development conditions of the rock. Alejano et al. [16] analyzed the failure mechanism of open-pit mine and interpreted the toppling and cyclic failure of rock slope as a composite toppling failure mode. Huang et al. [17] analyzed the mechanism of slope toppling deformation and divided its process into shallow toppling and deep toppling.

There are many factors inducing slope toppling deformation and failure, and scholars analyze the conditions of 
causing toppling deformation mainly with theory [18-21], numerical simulation [22-24], and centrifugal model test [25-28]. Some researchers conduct the centrifugal model test to study the bending deformation and analyze the influence of rock layer inclination, tensile strength, internal friction angle, and joint spacing on slope toppling deformation and failure $[18,29]$. Brideau and Stead [30] analyzed the effects of the dipping direction and angle of the structural plane and internal friction angle on the toppling deformation by $3 \mathrm{DEC}$. The tensile strength was considered to be the main factor of bending toppling deformation [31]. Some scholars thought that periodic fluctuation of reservoir water and long-term immersion in the water were the important factors that resulted in toppling failure [32, 33]. Yu et al. [34] numerically simulated a rock slope model with complex joints and exhibited the progressive failure processes. Some scholars simulated the excavation process of reverse-dip slope and analyzed the influence of rock thickness, slope inclination, and lithology on toppling deformation [35-37].

At present, many factors affecting the toppling deformation of rock slope are mentioned and studied. However, the toppling deformation of rock slope under the effect of rainfall is rarely considered and the slope is always regarded as integrity to analyze its toppling deformation and failure characteristics. Besides, many scholars generally studied the toppling deformation characteristics of the slopes by establishing engineering geological models but giving up mechanical models by which satisfying results can be yielded based on proper constitutive relations or limit equilibrium theory; in addition, it should be noticed that the mechanical model is difficult to be applied to bank defamation cases because of lacking monitoring data, and the influencing mechanism of external factors such as rainfall and reservoir water cannot be well solved by mechanical models. Therefore, considering that in situ deformation data is the most objective criterion for evaluating various mechanical models, a typical anti-inclined rock slope was adopted in this study to explore the toppling displacement evolution characteristics of bank slope under rainfall based on discrete actual displacement monitoring data, which is valuable to further understand the deformation and failure characteristics of anti-inclined slope and provide the reference for similar anti-inclined slope cases.

1.1. Project Overview. Xiaodongcao bank slope is located in the right bank of the upstream side of Xixi River, Zhongliang Town, Wuxi County, Chongqing, and is $1.2 \mathrm{~km}$ away from Zhongliang reservoir; its elevation ranges from $540 \mathrm{~m}$ to $1183 \mathrm{~m}$, the longitudinal length is about $900 \mathrm{~m}$, the width ranges from 400 to $650 \mathrm{~m}$, the inclination is $345^{\circ}$, and the vegetation is well developed (Figure 1). The middle and front of the slope are steep and the terrain slope is $45^{\circ} \sim 68^{\circ}$ with some parts nearly vertical, while the rear edge is relatively flat and the terrain slope ranges from $11^{\circ}$ to $18^{\circ}$. The rock mass of the bank slope is mainly the lower Triassic Jialingjiang formation (T1j) and Daye Formation (T1D). Jialingjiang formation ( $\mathrm{T} 1 j)$ is dolomitic limestone, which is located in the middle and front of the bank slope, and Daye Formation
(T1D) is argillaceous limestone, which is mainly located in the middle and rear of the bank slope.

Gullies are relatively developed; there are five large gullies flowing into Zhongliang reservoir mainly from north to south; the valleys are $\mathrm{V}$-shaped, and the bottom of the valley where the slope angle is $40^{\circ} \sim 60^{\circ}$ is steep and the width ranges from 5 to $25 \mathrm{~m}$, and groove cutting depth is from 20 to $50 \mathrm{~m}$. In the research area, the rainfall is abundant and the average annual rainfall is $1333 \mathrm{~mm}$; the rainy season is from April to October and accounts for $90 \%$ of the annual rainfall; the rainfall in January is the lowest and accounts for about $1 \%$. After the rainstorm and continuous heavy rainfall, Gullies G1 and G4 collapsed in different degrees, and their toppling deformation increased significantly.

1.2. Surface Displacement Monitoring System. To monitor the displacement of the Xiaodongcao bank slope, 22 surface displacement monitoring points were evenly distributed throughout the study area; among them, 17 monitoring points were arranged on the bank slope and 5 were arranged outside the bank slope. The monitoring period is from January to December 2017, and the research area can be divided into five cross sections and three longitudinal sections according to the layout of the monitoring system (Figure 2).

\subsection{Monitoring Results of Ground Displacement}

1.3.1. Longitudinal Displacement. The monitoring results of the longitudinal section of the bank slope midline 2-2' showed that the horizontal displacement (Figure 3(a)) gradually developed from the front to the rear edge of the bank slope and increased with the amount of rainfall; the vertical displacement (Figure 3(b)) developed from the front to the back of the bank slope with larger displacement in the middle and first increased and then decreases; when the rainfall reached the peak, the trailing edge went upward, which was mainly manifested as the bending and toppling deformation of the reverse-dip rock slope.

1.3.2. Horizontal Displacement. The monitoring results of the $\mathrm{C}-\mathrm{C}^{\prime}$ cross section in the middle of the bank slope (Figure 4) show that the horizontal displacement on the right side of the bank slope was greater than that on the left side while the vertical displacement shows the opposite trend. The vertical displacement in the middle was larger than other sides and increased with the amount of rainfall; it reached the peak when the rainfall was the maximum. It can be concluded that the right side of the bank slope is dominated by horizontal displacement and the middle part is dominated by vertical displacement.

1.4. Superposition Partition Based on Development Characteristic Factors. Hypsometric Integral (HI) is an important indicator that reflects the degree of landform erosion by counting the surface elevation of the watershed and thereby reveals the morphology and development characteristics of 

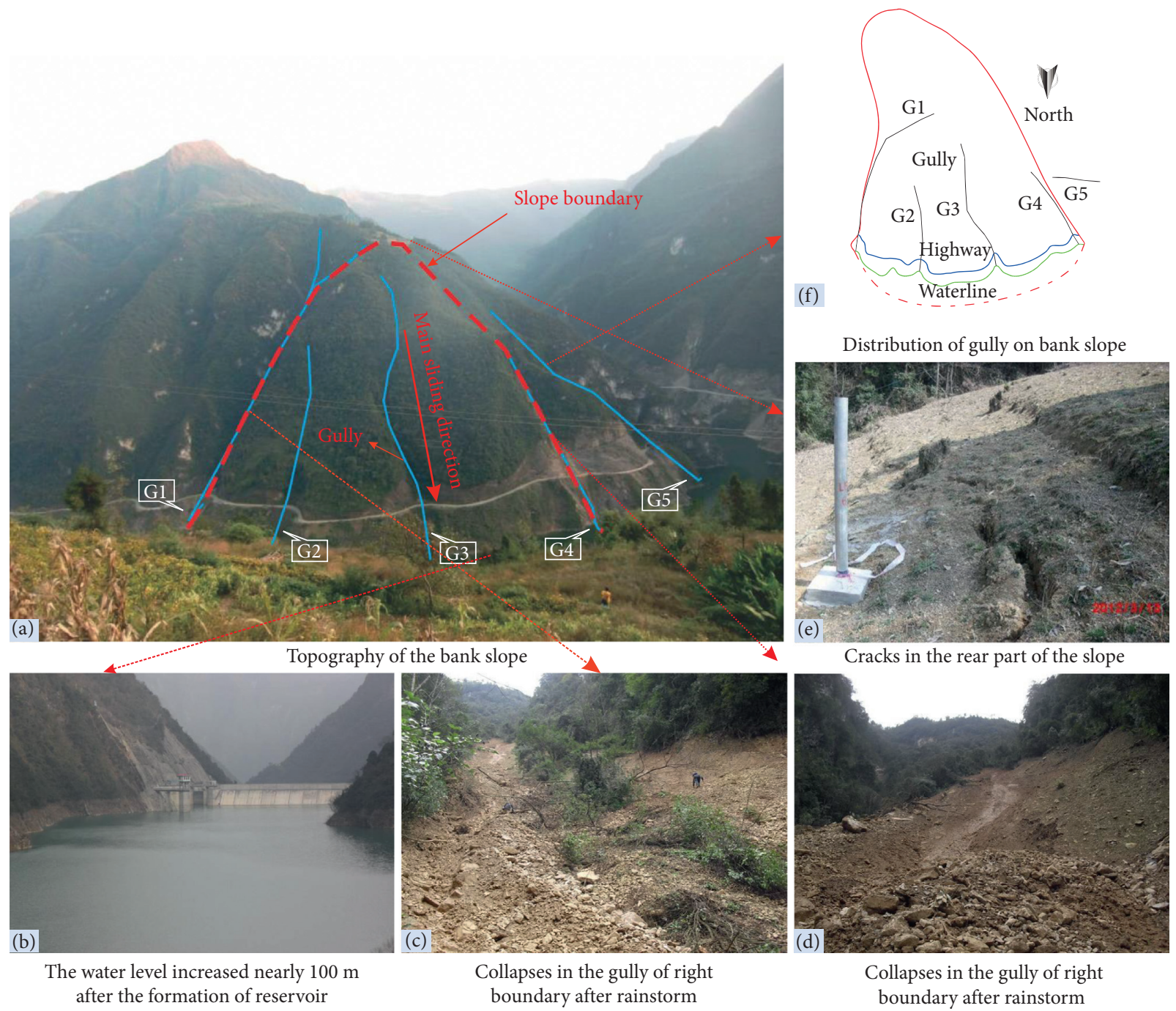

Figure 1: Toppling deformation and failure of the slope after the rainstorm. (a) Topography of the bank slope, (b) the water level increased nearly $100 \mathrm{~m}$ after the formation of the reservoir, (c) collapses in the gully of right boundary after a rainstorm, (d) collapses in the gully of right boundary after a rainstorm, (e) cracks in the rear part of the slope, and (f) distribution of gully on bank slope.

the watershed. In the 1950s, geomorphologists [38] applied the area integral curve to independent small watersheds to quantify the W. Davies landform development model [39]. According to the area-elevation integral value, they divided the landform development process into three stages: young stage $(\mathrm{HI}>0.6)$, mature stage $(0.35<\mathrm{HI}<0.6)$, and old age stage $(\mathrm{HI}<0.35)$. The calculation process is as follows: $X=a /$ $A, Y=h / H, X$, and $Y$ are within $[0,1]$ ( $A$ is the area of the whole watershed, $a$ is the area above some contour line in the watershed, $h$ is the height difference between the contour line and the lowest point of the watershed, and $H$ is the height difference between the highest and lowest point of the watershed); the area-elevation curve can be drawn with $X$ as the abscissa and $Y$ as the ordinate, and the area between the abscissa and the curve is defined as the area-elevation integral value. Based on the engineering geological survey of bank slope, the flow direction and flow of the bank slope were analyzed using the ArcGIS hydrological analysis tool, and the number of bank slope watersheds and the corresponding area-elevation integral values under different confluence accumulations were obtained. As shown in Figure 5, most areas of the bank slope were in young and mature stages. Due to the vertical and horizontal cutting of bank slope valleys and the development of gullies, buffer zones with different distances of $10 \mathrm{~m}, 30 \mathrm{~m}$, and $50 \mathrm{~m}$ were formed. Besides, the overall terrain of the bank slope is steep, and the terrain slope of most areas is greater than $40^{\circ}$, except that the trailing edge is relatively flat (the terrain slope angle is from 0 to $31^{\circ}$ ).

Therefore, by taking the slope of the bank, gully buffer zone, and the HI value of the watershed as the development characteristic factors, geometric superposition characteristic zones of the bank slope can be obtained by ArcGIS layer superposition based on Table 1 and the bank slope was finally divided into 104 characteristic zones (Figure 5).

The area of every characteristic zone in Figure 6 was calculated by ArcGIS geometry, the total area was $96999.12 \mathrm{~m}^{2}$, the influence of characteristic zones with a 


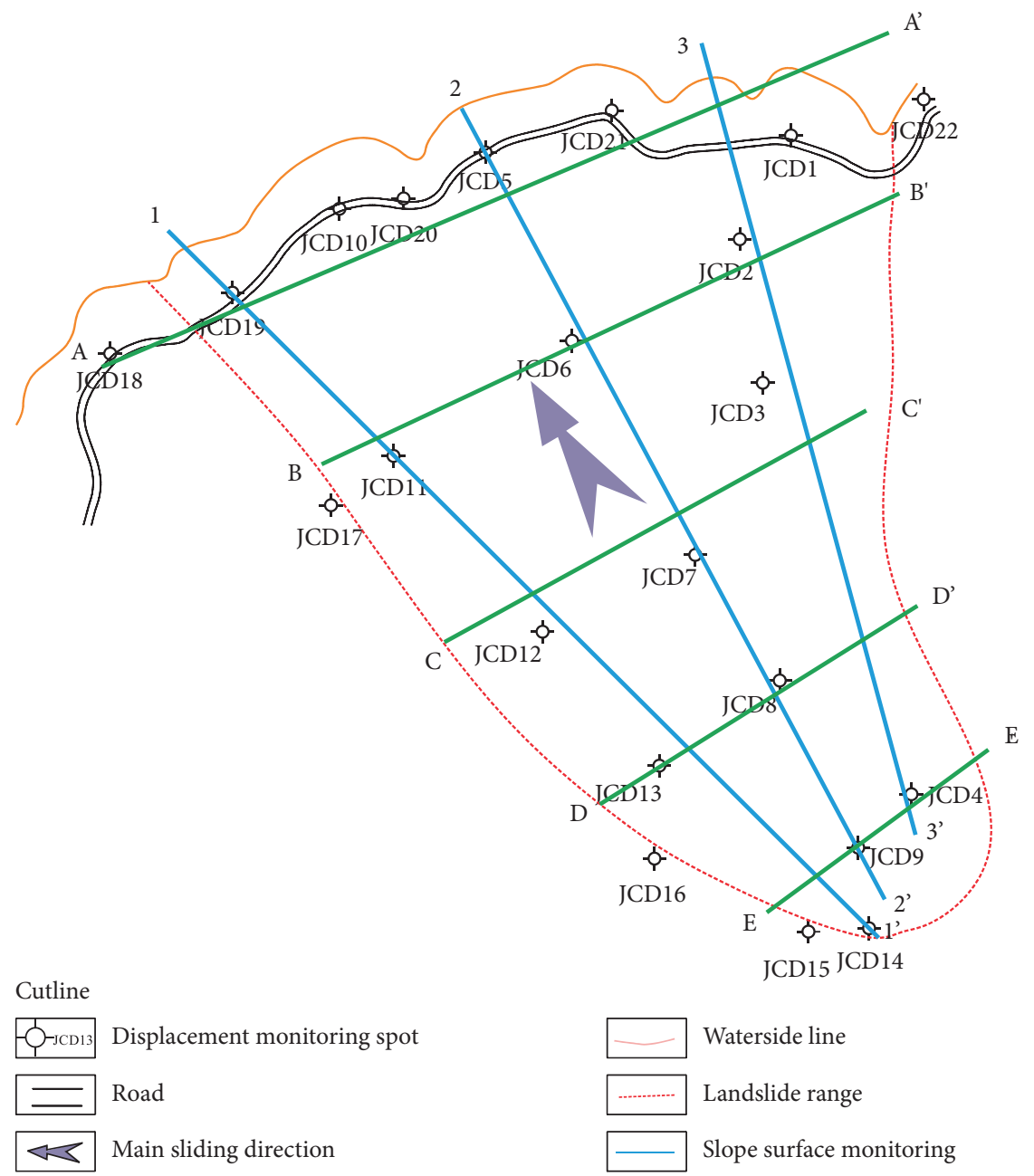

FIGURE 2: Layout of monitoring points of the slope.

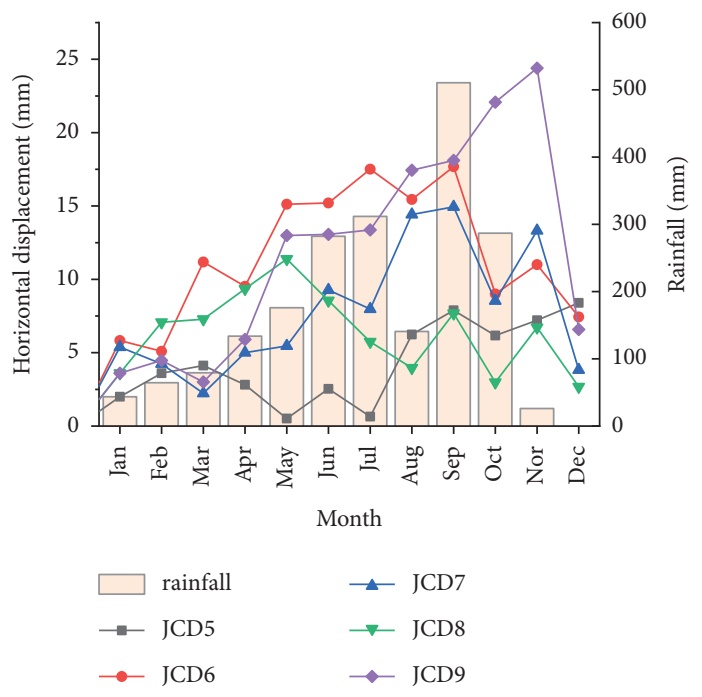

(a)

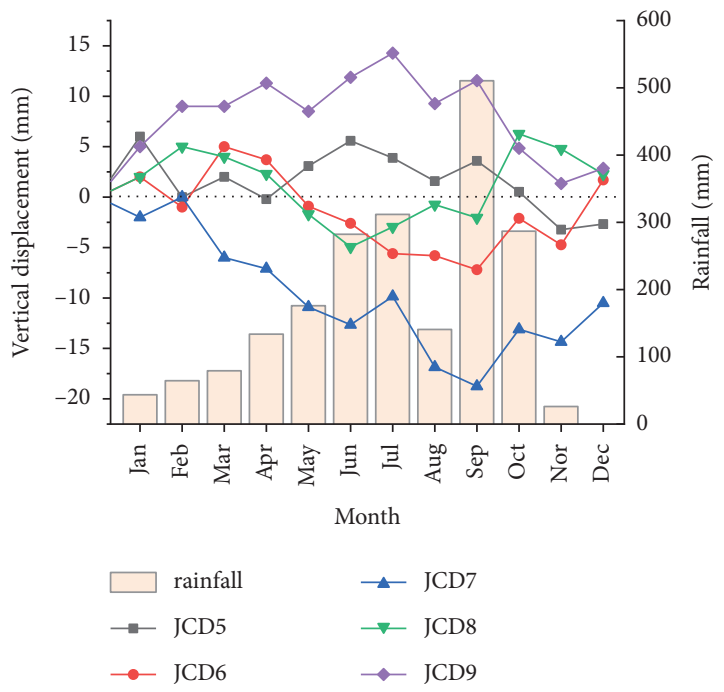

(b)

FIgURE 3: Monitoring curve of surface displacement with the rainfall of 2-2' longitudinal section of bank slope. 


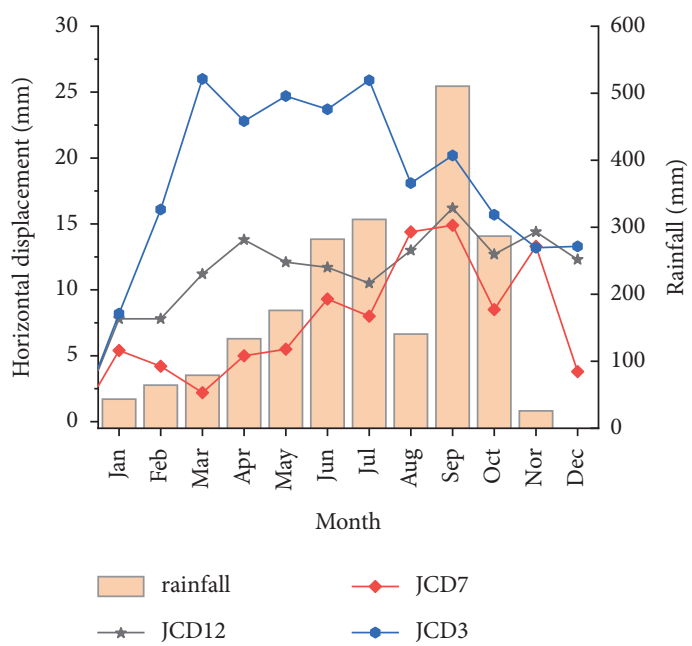

(a)

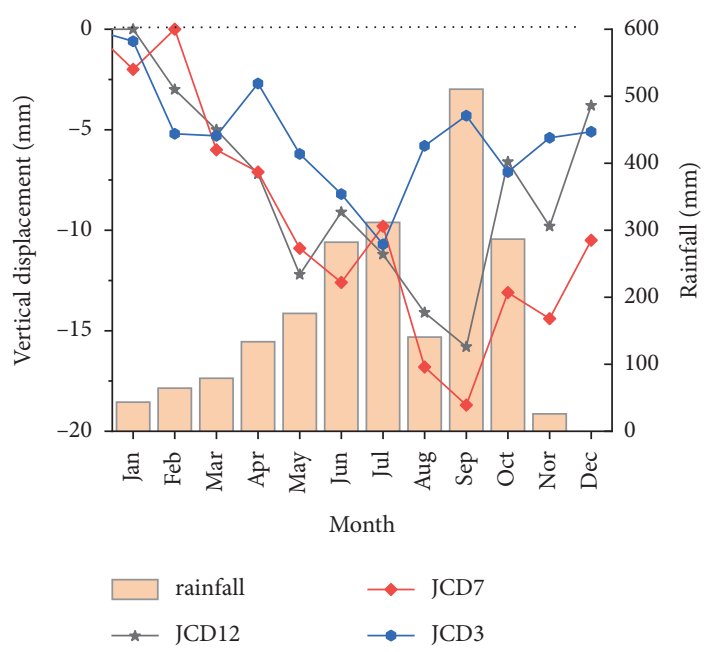

(b)

FIGURE 4: Monitoring curve of surface displacement with the rainfall of the $C-C^{\prime}$ cross section of bank slope.
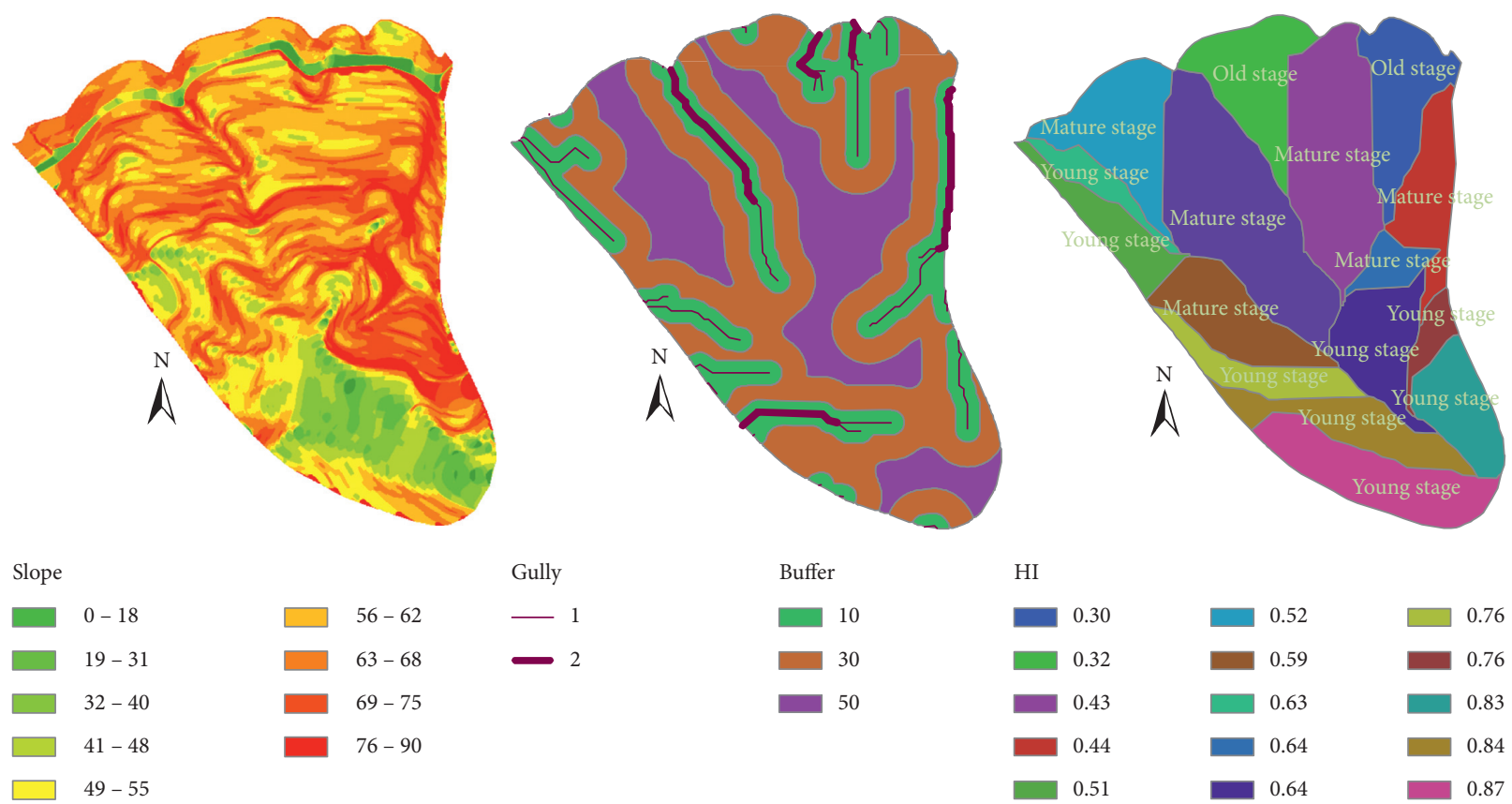

HI

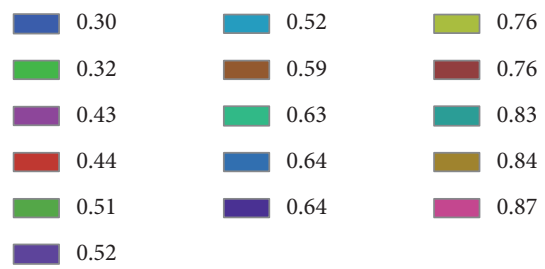

FIgURE 5: Distribution of the slope, buffer, and hypsometric integral.

small area can be ignored, and the cumulative area of characteristic zones whose area is larger than $1500 \mathrm{~m}^{2}$ accounts for $64.48 \%$. Zone 232 with a high slope (the highlight zone in Figure 6), which forms a $10 \mathrm{~m}$ buffer zone and is at the mature stage, is located in gully G3 and holds the largest area $\left(3761.32 \mathrm{~m}^{2}\right)$ among all the characteristic zones (Figure 7).

1.5. Spatial and Temporal Evolution Nephogram of Toppling Displacement. Due to the abundant rainfall, especially rainstorms or continuous heavy rainfall in the flood season, gullies G1 and G4 collapsed in different degrees, and their collapse deformation was significantly intensified with water infiltration through cracks. The annual rainfall in 2017 is $2054.34 \mathrm{~mm}$, which is the maximum in the last nine years (Figure 8), and the cumulative rainfall of each month is calculated and shown in Table 2. It can be seen that the rainy season was from May to October, and the rainfall in July was $510.60 \mathrm{~mm}$ and the highest, accounting for $24.85 \%$ of the annual rainfall, but there was no rain in December. For a brief description, all the months are numbered in Table 2 . The bank slope toppling deformation was real-time monitored, the distance inverse weighting method was used to 
TABLE 1: Basis for the geometrical zone of bank slope.

\begin{tabular}{|c|c|c|c|}
\hline Type & Slope & Buffer & $\mathrm{HI}$ \\
\hline Level & $\begin{array}{l}\text { 1: } 0^{\circ}-40^{\circ} \\
\text { 2: } 41^{\circ}-62^{\circ} \\
\text { 3: } 63^{\circ}-90^{\circ}\end{array}$ & $\begin{array}{l}\text { 1: } 10 \mathrm{~m} \\
\text { 2: } 30 \mathrm{~m} \\
\text { 3: } 50 \mathrm{~m}\end{array}$ & $\begin{array}{c}\text { Assign values according to the value of } \mathrm{HI} \text { from small to large; for example, if the value of } \mathrm{HI} \text { is } 0.3 \text {, it is } \\
\text { represented by } 1\end{array}$ \\
\hline
\end{tabular}
Unite

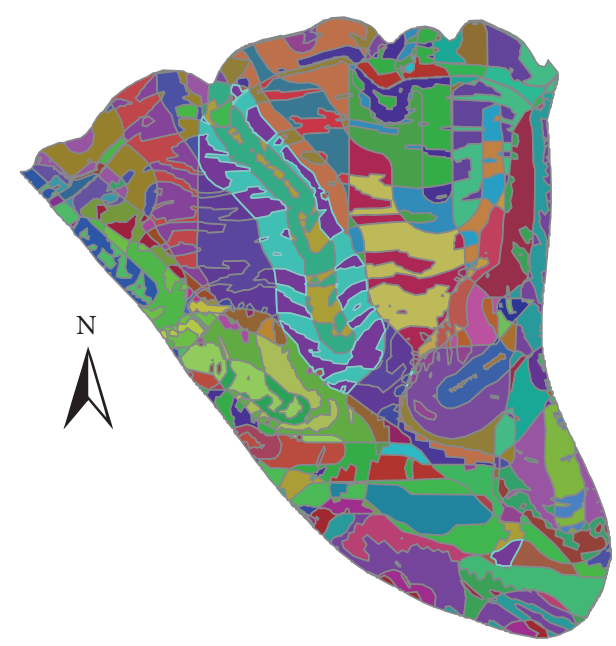

Legend

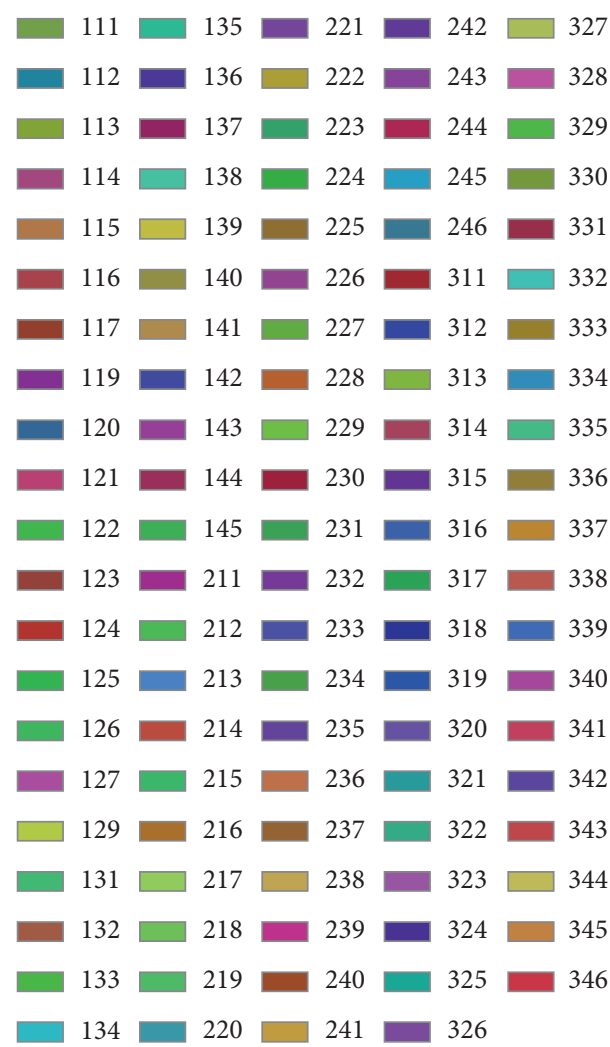

Figure 6: Partition map of the slope based on the geometrical conditions.

interpolate the displacement nephogram under different rainfalls based on the discrete displacement monitoring data on the surface, and then the evolution characteristics of the

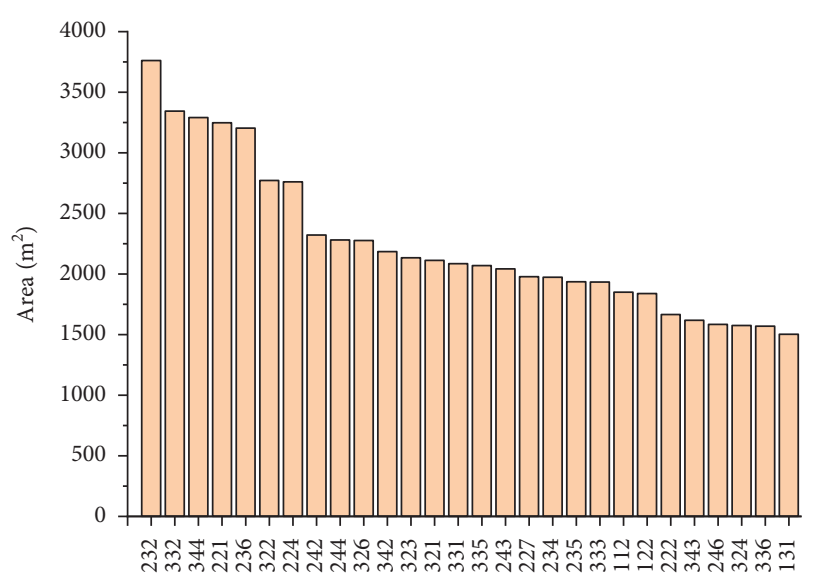

Charecteristic zone

FIGURE 7: Bank slope geometric partitioning unit area of statistical results.

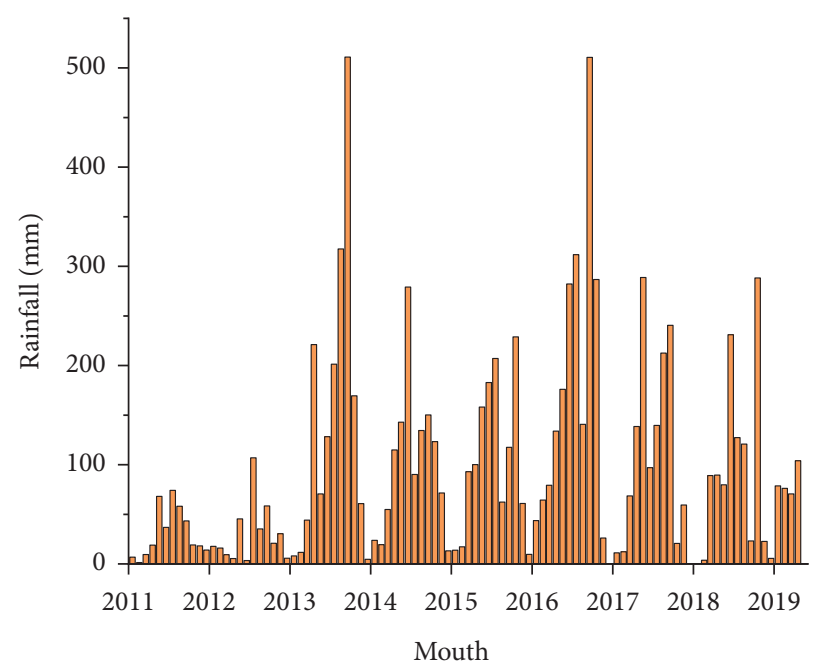

FIGURE 8: Cumulative monthly rainfall in recent nine years of bank slope.

horizontal, vertical, and total displacement spatial-temporal evolution nephogram were analyzed.

1.6. Spatial-Temporal Evolution Nephogram of Horizontal Displacement. Figure 9 is the cloud map of the horizontal displacement under the condition of different rainfalls. The natural breaks (Jenks) method [40] was used to classify the horizontal displacement into ten grades and the zones where the horizontal displacement is greater than $16.03 \mathrm{~mm}$ were defined as the obvious horizontal deformation zone. 
TABLE 2: Cumulative monthly rainfall in 2017.

\begin{tabular}{lccccccccccccc}
\hline Month & Jan & Feb & Mar & Apr & May & Jun & Jul & Aug & Sep & Oct & Nor & Dec & Total \\
\hline Rainfall $(\mathrm{mm})$ & 43.5 & 64.3 & 79.1 & 133.7 & 175.97 & 282.2 & 311.67 & 140.6 & 510.6 & 286.7 & 26 & 0 & 2054.34 \\
Number & A & B & C & D & E & F & G & I & J & K & L & M & N \\
\hline
\end{tabular}
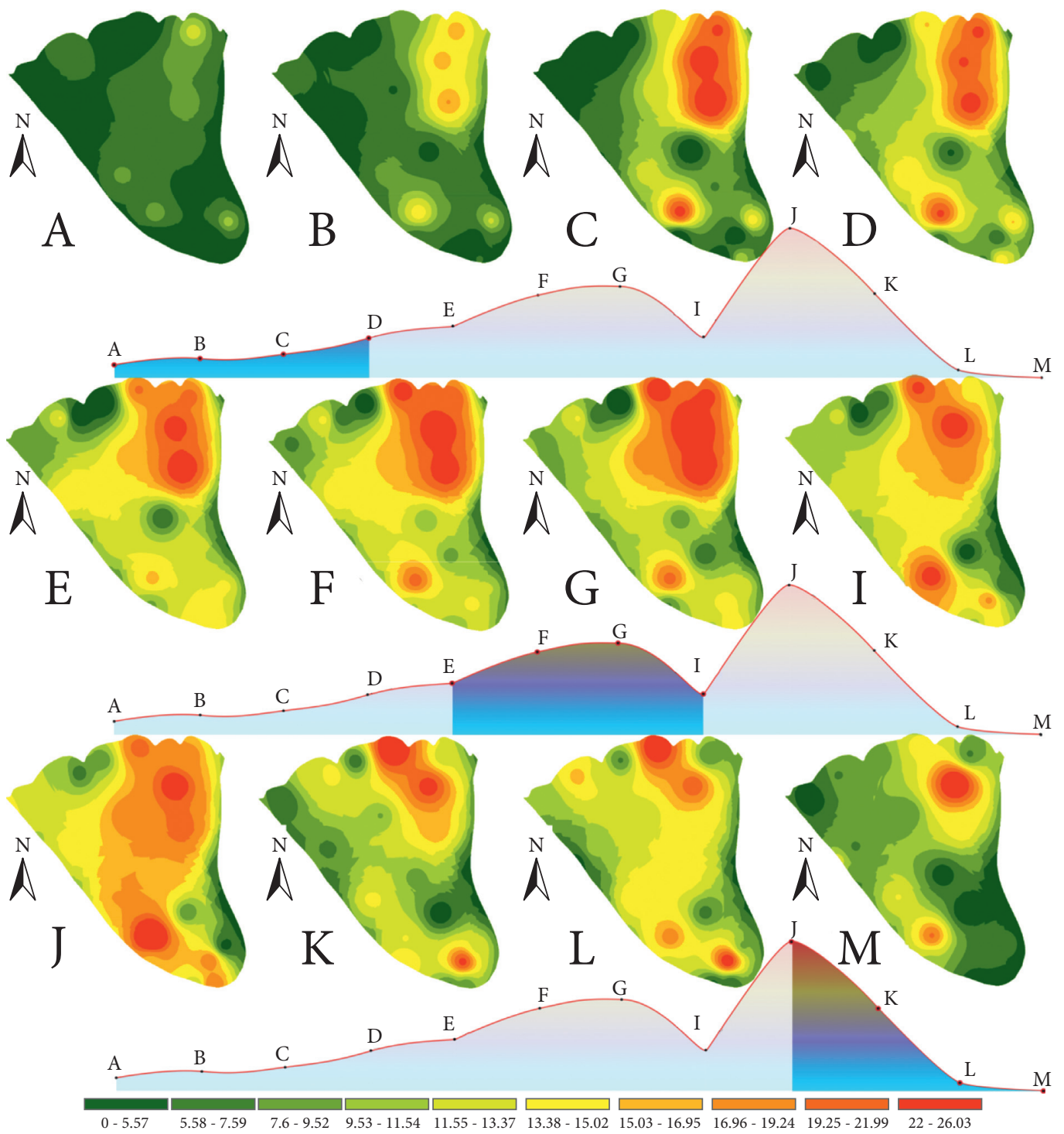

Figure 9: Temporal and spatial evolution characteristics of horizontal displacement of bank slope toppling ( $\mathrm{mm}$ ).

Obvious horizontal deformation zones were mainly located in the right front of the bank slope, and some were on the left side of the trailing edge of the bank slope. The change of horizontal displacement mainly extended from the right front to the middle and the left of the trailing edge, forming an "S" shape, and the maximum horizontal displacement occurred in the middle front between gullies G1 and G2. As shown in Figure 10, the horizontal deformation of the bank slope was sensitive to the rainfall and increased with the amount of rainfall. The area of the obvious horizontal deformation zones reached the peak value of $34286.85 \mathrm{~m}^{2}$ when the rainfall was the highest value of $510.60 \mathrm{~mm}$ in July; this value was $4815.49 \mathrm{~m}^{2}$ in December without rainfall. In flood season, the total area of obvious horizontal deformation zones was $126654.10 \mathrm{~m}^{2}$ and accounts for $74.61 \%$, which is larger than that in the nonflood season with an area of $43083.64 \mathrm{~m}^{2}$.

1.7. Spatial-Temporal Evolution Nephogram of Vertical Displacement. Figure 11 shows the cloud map of vertical displacement under the condition of different rainfalls. The natural breaks (Jenks) method was used to classify the vertical displacement into ten grades and the zones where the vertical displacement is smaller than $-6.88 \mathrm{~mm}$ were defined as the obvious vertical deformation zones. Obvious 


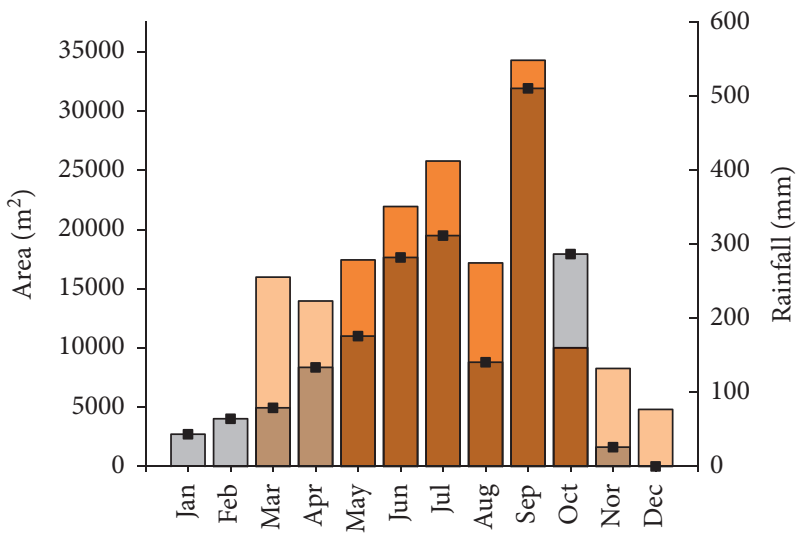

Month

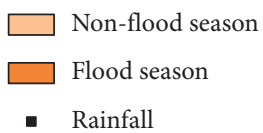

FIGURE 10: Area variation of obvious horizontal deformation zones.
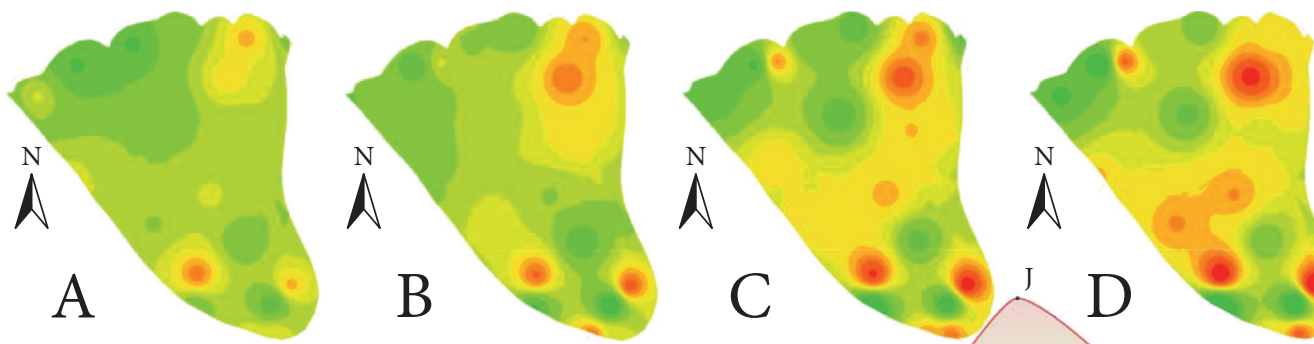

B
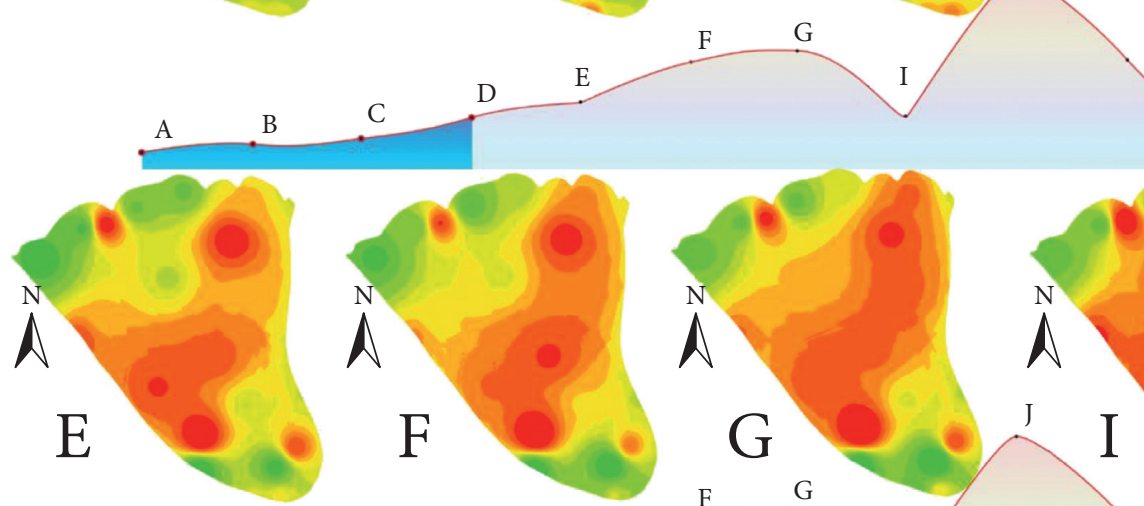

D

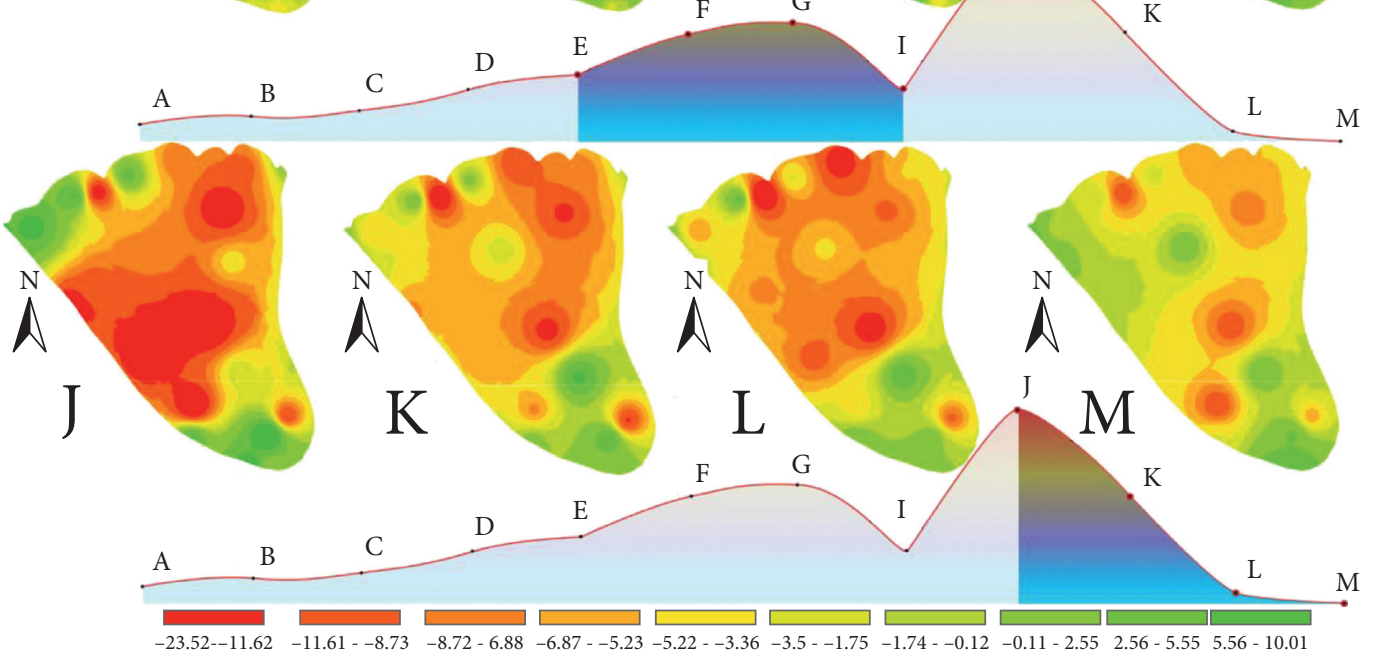

FIgURE 11: Temporal and spatial evolution characteristics of vertical displacement of bank slope toppling (mm). 


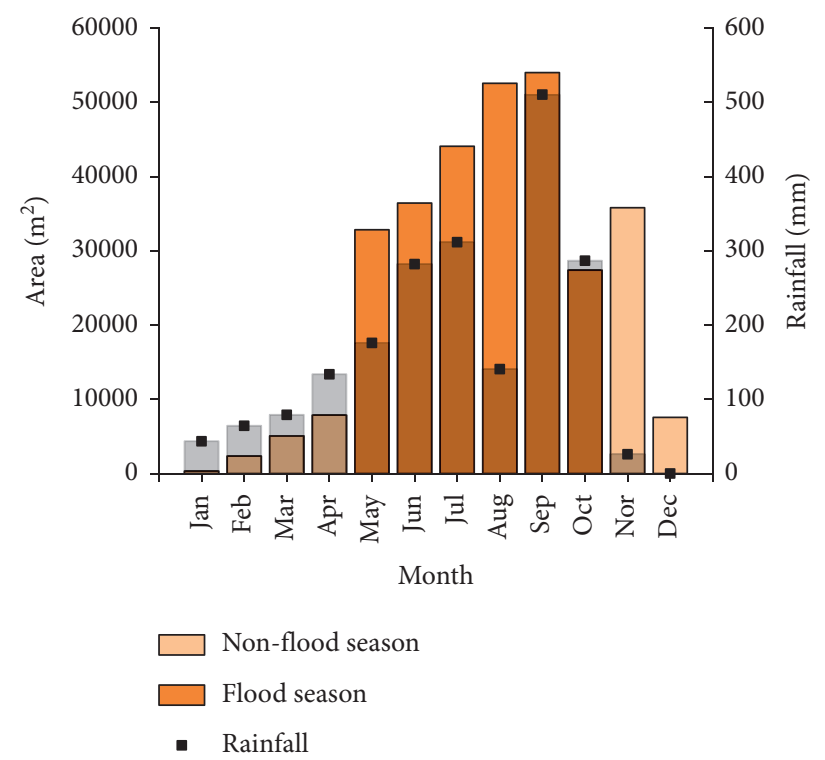

Figure 12: Area variation of obvious vertical deformation zones.
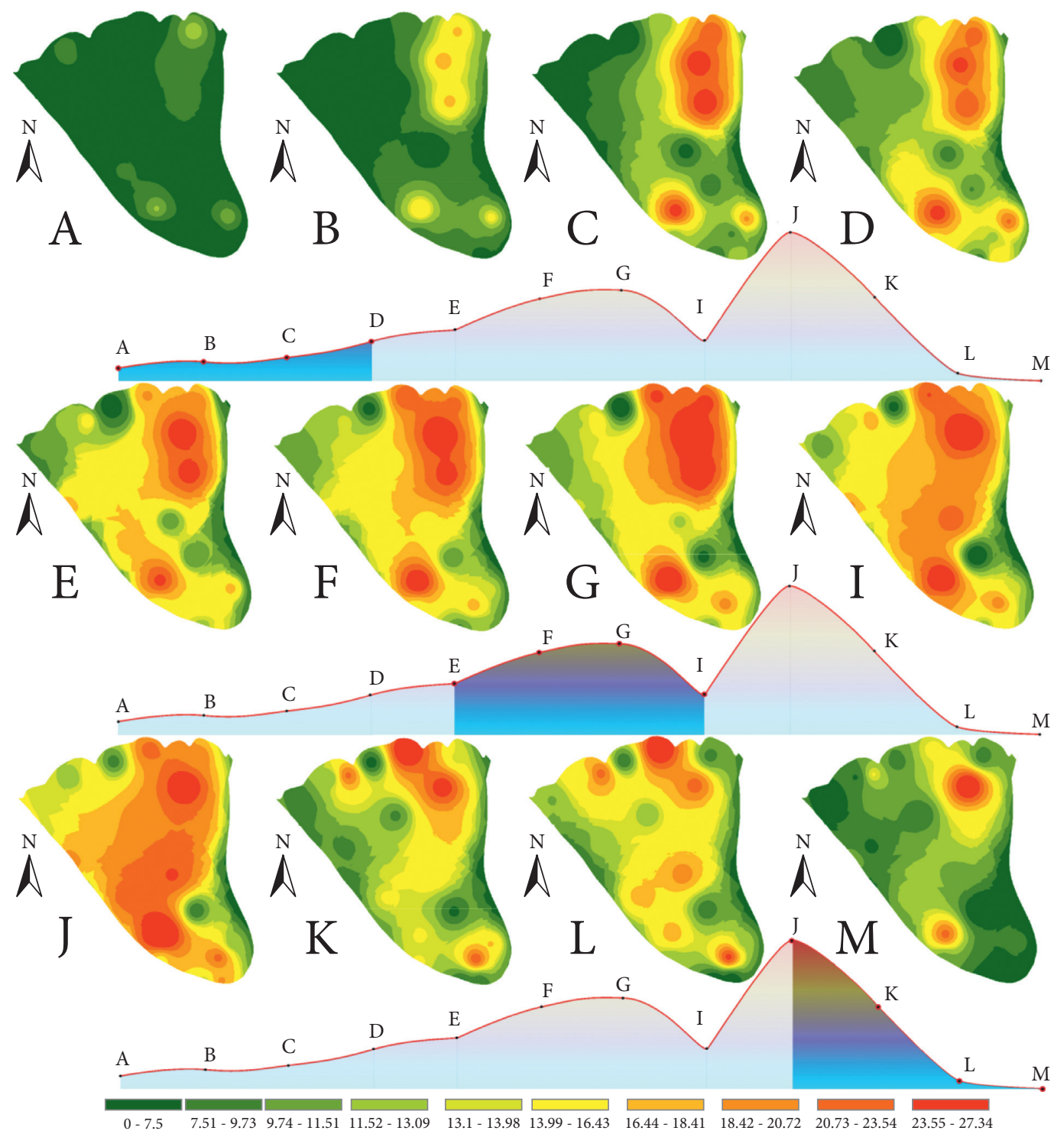

FIgURE 13: Temporal and spatial evolution characteristics of the total displacement of bank slope toppling (mm). 


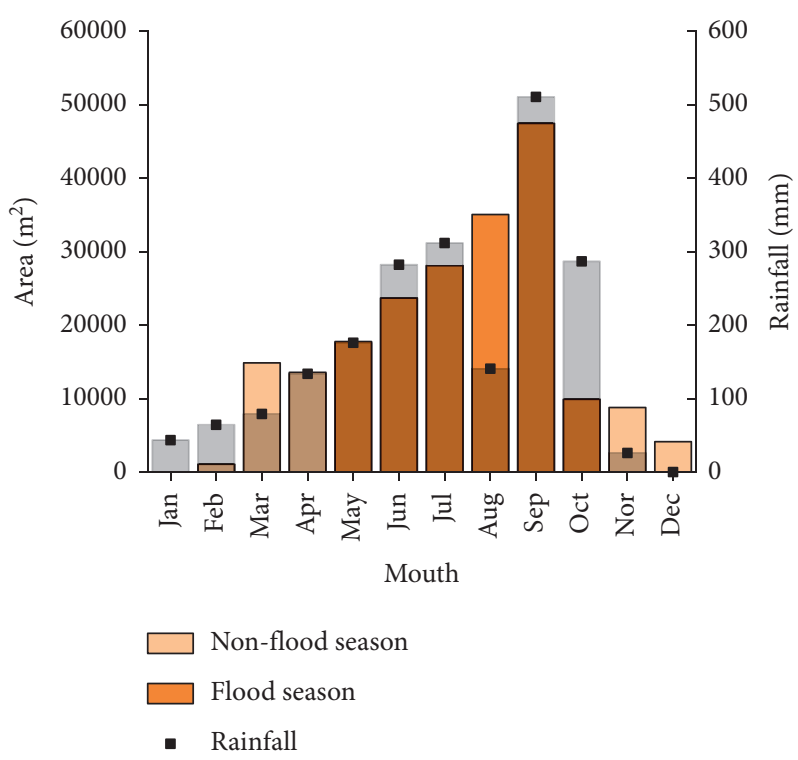

FIgURE 14: Area variation of obvious total deformation zones.

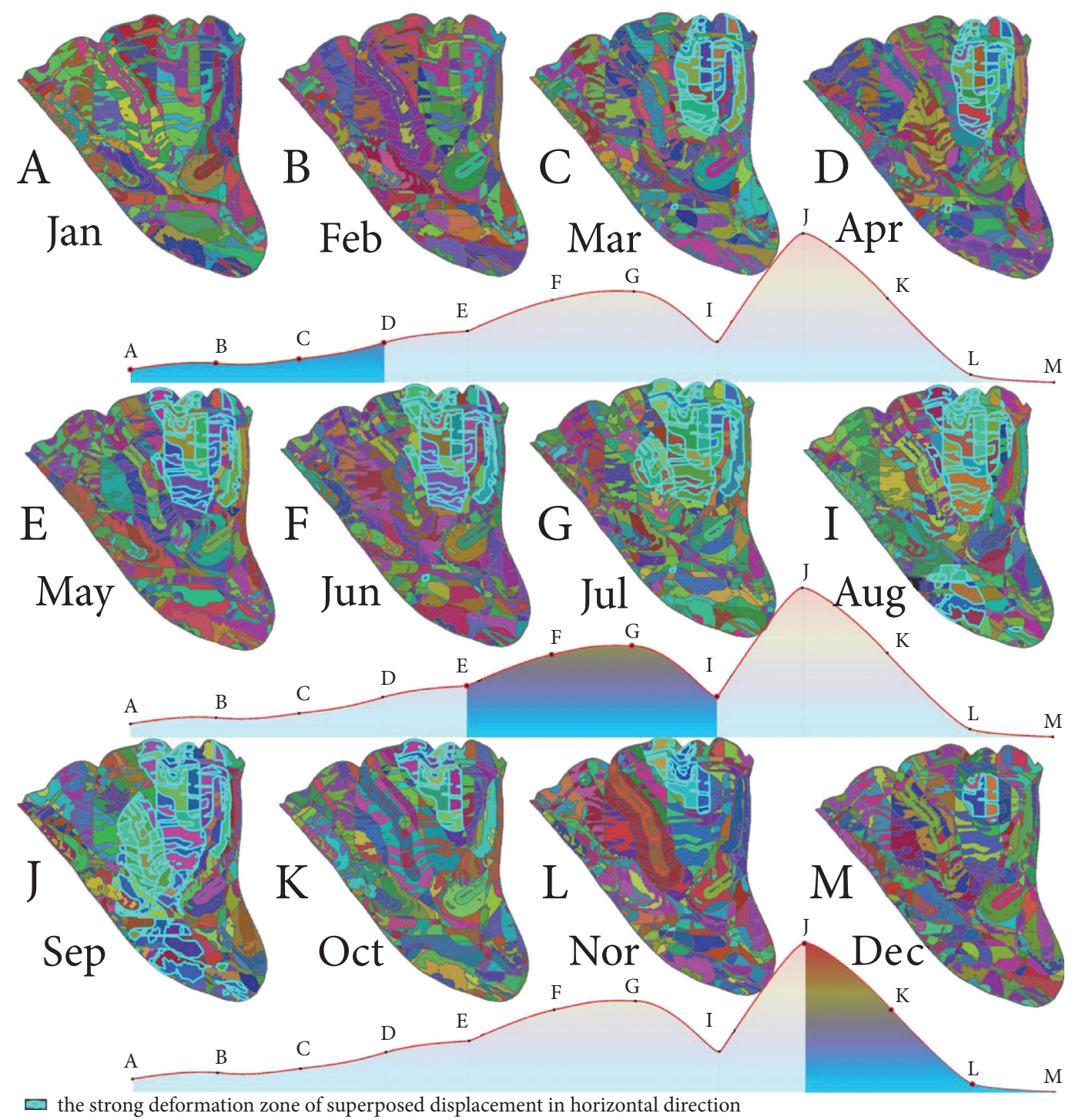

Figure 15: Evolution of the superposed displacement in the horizontal direction based on the development characteristic partition. 


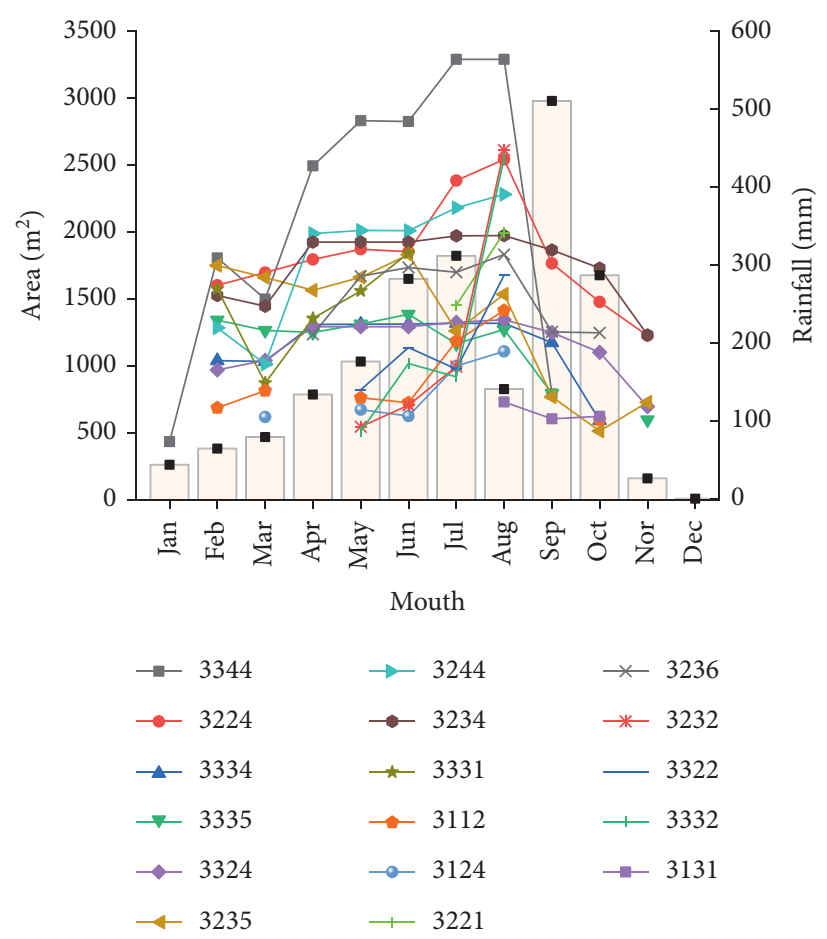

Figure 16: Area variation of the characteristic zone of strong deformation of superposed displacement in the horizontal direction under different rainfalls.

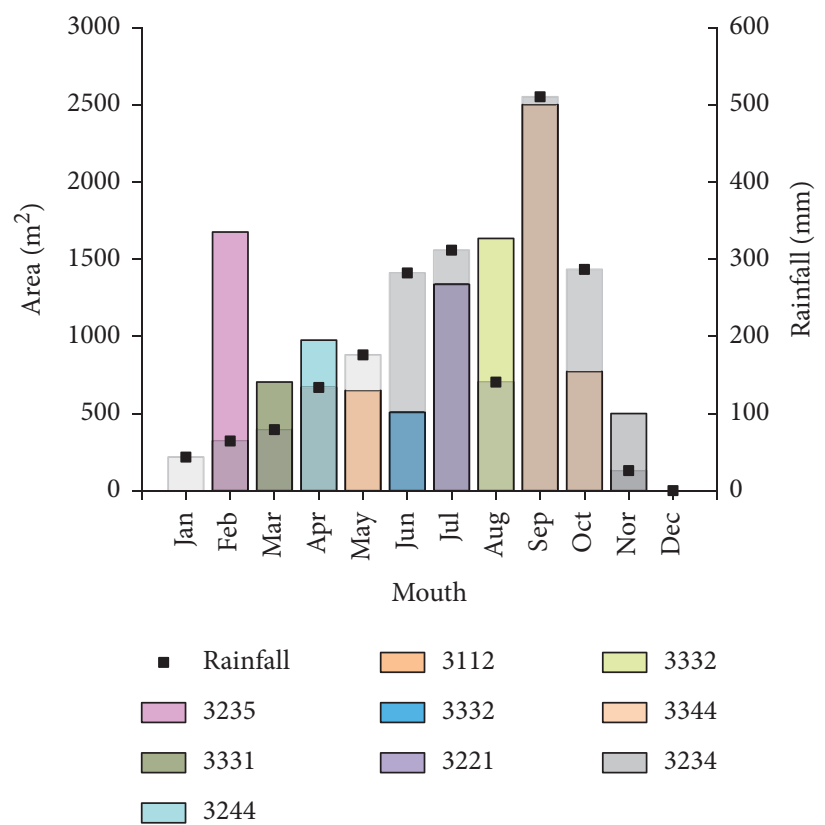

FIgURE 17: Diagram of the area of active characteristic zone in relation to the superposed displacement in the horizontal direction.

vertical deformation zones were mainly located in the middle of the bank slope, and the maximum vertical displacement occurred on the right side of the middle of the bank slope. As shown in Figure 12, the vertical displacement increased with the amount of rainfall. From January to September, the area of zones with obvious vertical deformation which extends from the right front of the bank slope to the middle gradually increased with the amount of rainfall and reached the maximum value of $54031.06 \mathrm{~m}^{2}$ in September when the rainfall was the highest and $510.60 \mathrm{~mm}$. After September, this area gradually decreased to $7561.79 \mathrm{~m}^{2}$ in December without rainfall. In flood season, the area of the zone with obvious vertical deformation was $247417.77 \mathrm{~m}^{2}$ and accounted for $80.07 \%$; it was larger than $59023.42 \mathrm{~m}^{2}$ in 


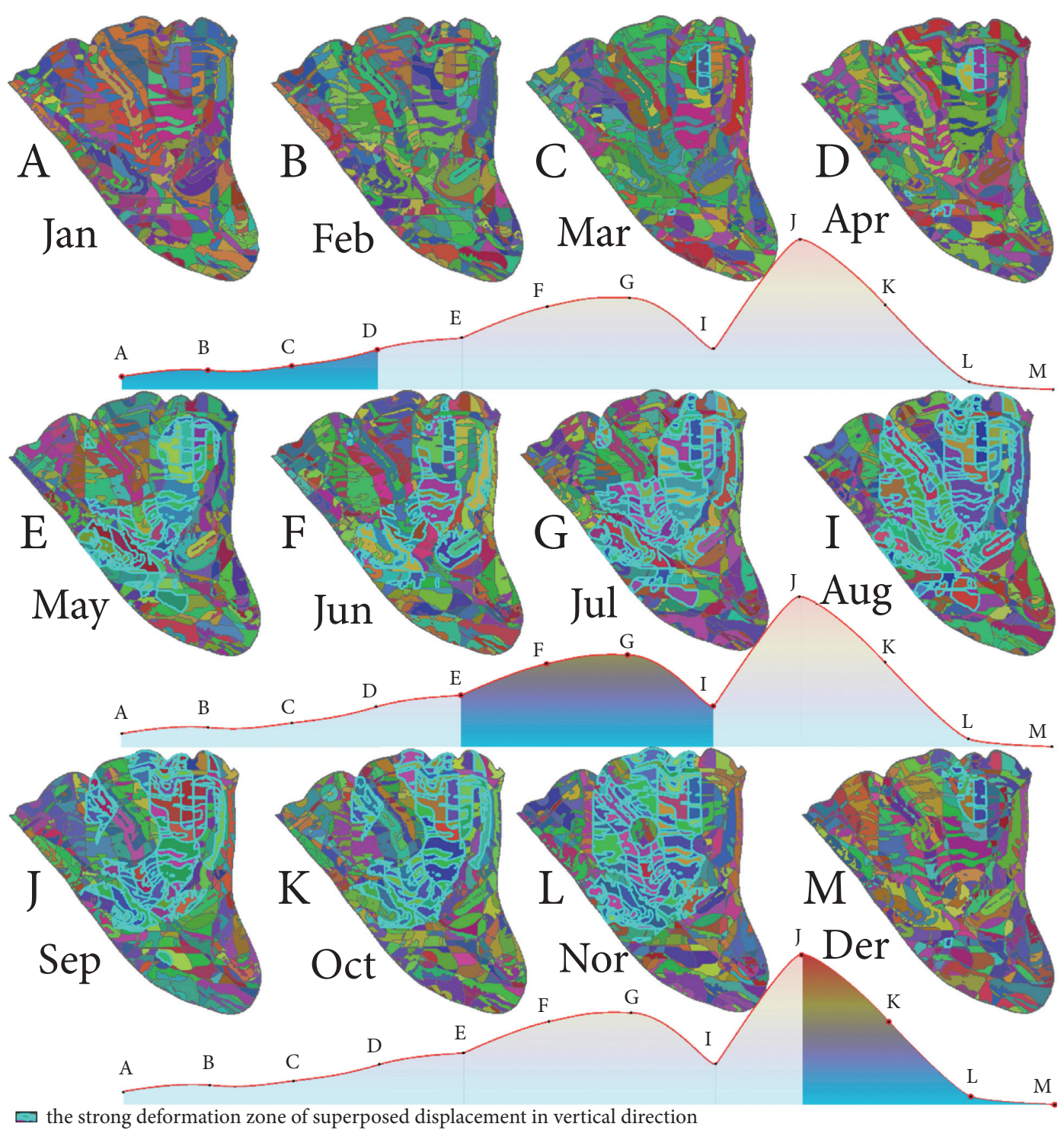

FigURE 18: Evolution of the superposed displacement in the vertical direction based on the development characteristic partition.

the nonflood season, so it can be inferred that the vertical displacement is more sensible to rainfall than horizontal displacement.

1.8. Spatial-Temporal Evolution Nephogram of Total Displacement. Figure 13 shows the cloud map of total displacement under the condition of different rainfalls. The natural breaks (Jenks) method was used to classify the total displacement into ten grades and the zones where the total displacement is greater than $18.42 \mathrm{~mm}$ were defined as the obvious deformation zone. Obvious deformation zones were mainly located in the right front and middle rear of the bank slope. The area of obvious deformation zones reached the maximum value of $47455.16 \mathrm{~m}^{2}$ when the rainfall was the highest and decreased to $4141.94 \mathrm{~m}^{2}$ in December without rainfall (Figure 14). The total displacement distribution is similar to the horizontal displacement and S-shape in the front and rear edge of the bank slope while the total displacement distribution is similar to vertical displacement in the middle of the bank slope, which means that the middle features vertical displacement and the front and rear edge features horizontal displacement.

\subsection{Toppling Displacement Evolution Characteristic Based on Development Characteristic Partition}

1.9.1. Analysis of Horizontal Toppling Evolution. The horizontal displacement nephogram under the condition of different rainfalls was classified into three grades using the Jenks natural breaks method: weak horizontal deformation zone where the horizontal displacement is smaller than $9.42 \mathrm{~mm}$ is represented by 1 , medium horizontal deformation zone where the horizontal displacement ranges from $9.42 \mathrm{~mm}$ to $14.53 \mathrm{~mm}$ is represented by 2, and strong horizontal deformation zone where the horizontal displacement is larger than $14.53 \mathrm{~mm}$ is represented by 3 . Based 


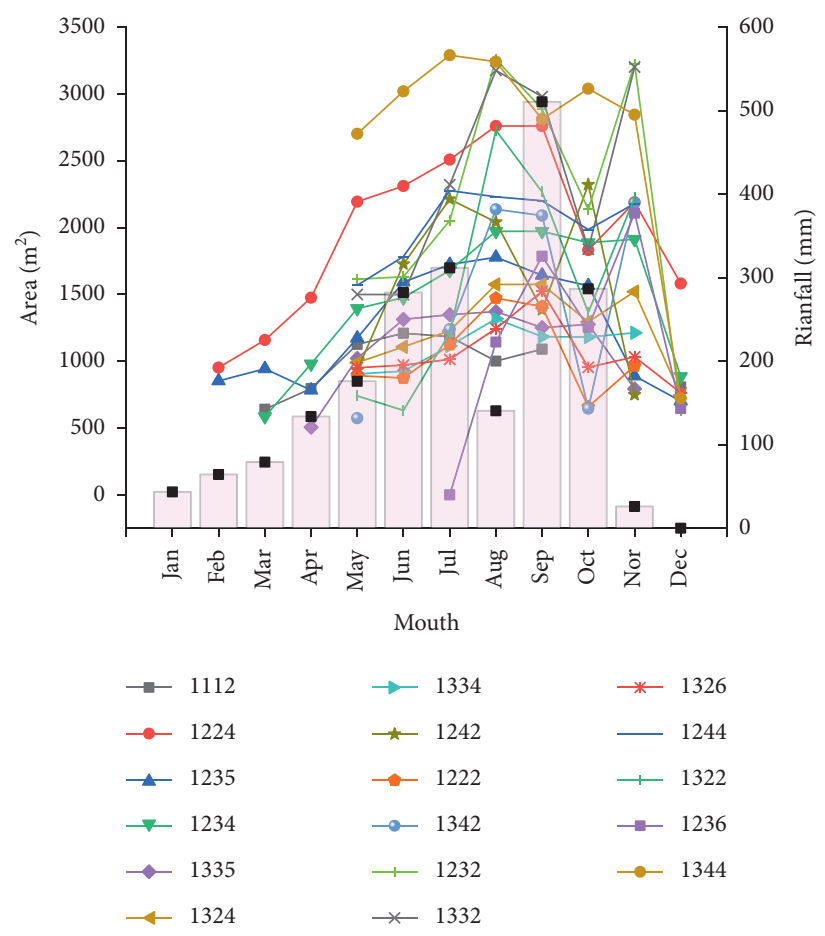

FIgURE 19: Area variation of the characteristic zone of strong deformation of superposed displacement in the vertical direction under different rainfalls.

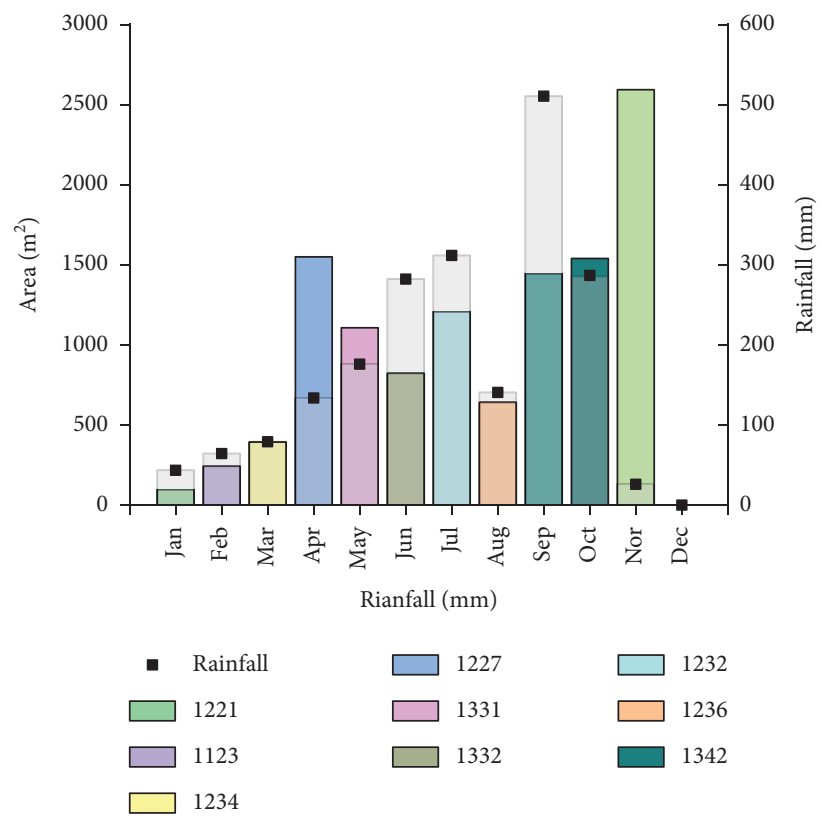

FIgURE 20: Diagram of the area of active characteristic zone concerning the superposed displacement in the vertical direction.

on the development characteristics partition (Figure 6), the evolution nephogram of the horizontal displacement based on geometric features was obtained through the superposition of ArcGIS raster layers (Figure 15).

The strong deformation zones of superposed displacement in the horizontal direction can be obtained through GIS in Figure 15. The influence of a zone with a small area is ignored, the strong deformation zones with an area larger than $1000 \mathrm{~m}^{2}$ are counted, and the zones with an area change rate greater than $15 \%$ are selected. As shown in Figure 16, under different amounts of rainfall, the variation of the area of strong deformation zones was analyzed, and it can be found that the area increased with the amount of rainfall and reached the peak when the rainfall was the highest value of $510.60 \mathrm{~mm}$ and then decreased with rainfall reducing. Zone 3344 was the largest strong deformation zone where the area 


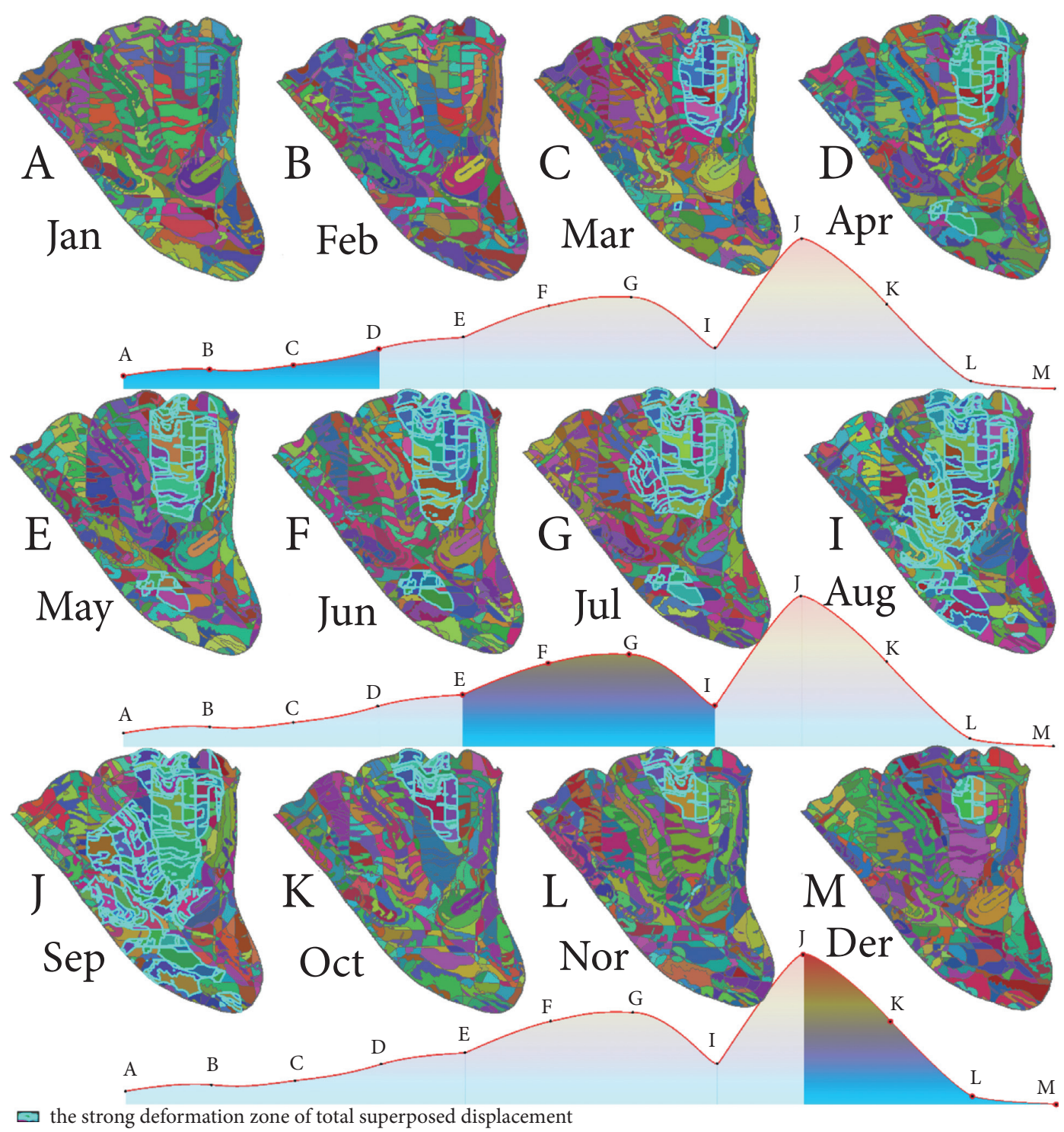

FIGURE 21: Evolution of the superposed displacement in the total direction based on the development characteristic partition.

was $3290 \mathrm{~m}^{2}$ and the peak rainfall was $510.60 \mathrm{~mm}$; at the same time, it is featured by medium to high slope and mature stage and formed a $50 \mathrm{~m}$ buffer zone. Under different rainfalls, the strong deformation zone accompanying the largest area change was defined as the displacement prone zone. As shown in Figure 17, when the rainfall decreased from $510.60 \mathrm{~mm}$ to $286.70 \mathrm{~mm}$, the area change of Zone 3344 was $2502.23 \mathrm{~m}^{2}$ with an area changing rate of $76.5 \%$.

1.9.2. Analysis of Vertical Toppling Evolution. Similarly, the vertical displacement nephogram under the condition of different rainfalls was classified into three grades using the Jenks best natural fracture method: weak vertical deformation zone where the vertical displacement is greater than $-1.77 \mathrm{~mm}$ is represented by 1 ; medium vertical deformation zone where the vertical displacement ranges from $-4.82 \mathrm{~mm}$ to $-1.77 \mathrm{~mm}$ is represented by 2 ; strong vertical deformation zone where the vertical displacement is smaller than
$-4.81 \mathrm{~mm}$ is represented by 3 . Based on the geometrical partition (Figure 6), the evolution nephogram of the vertical displacement based on geometric features was obtained through the superposition of ArcGIS raster layers (shown in Figure 18).

The strong deformation zones of superposed displacement in the vertical direction can be obtained through GIS in Figure 18. The influence of a zone with a small area was ignored, the strong deformation zones with an area larger than $1000 \mathrm{~m}^{2}$ were counted, and the zones with an area change rate greater than $15 \%$ were selected. As shown in Figure 19, the area variation of strong deformation zones under different rainfalls is explored, and it can be seen that the area of every strong deformation zone increased with the rainfall amount and reached the maximum when the rainfall was the peak value of $510.60 \mathrm{~mm}$ and then decreased. Zone 1344 had the largest area of $3290 \mathrm{~m}^{2}$, was featured by medium and high slope and mature stage, and formed a $50 \mathrm{~m}$ buffer zone. As shown in Figure 20, Zone 1232 located in the 


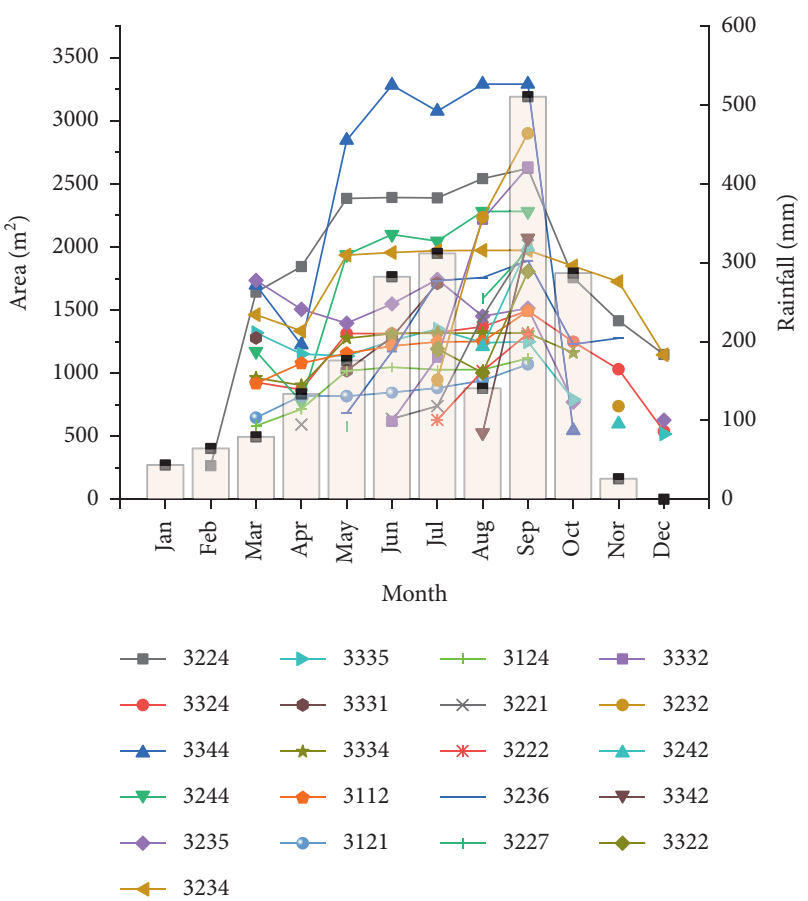

FIGURE 22: Area variation of the characteristic zone of strong deformation of total superposed displacement under different rainfalls.

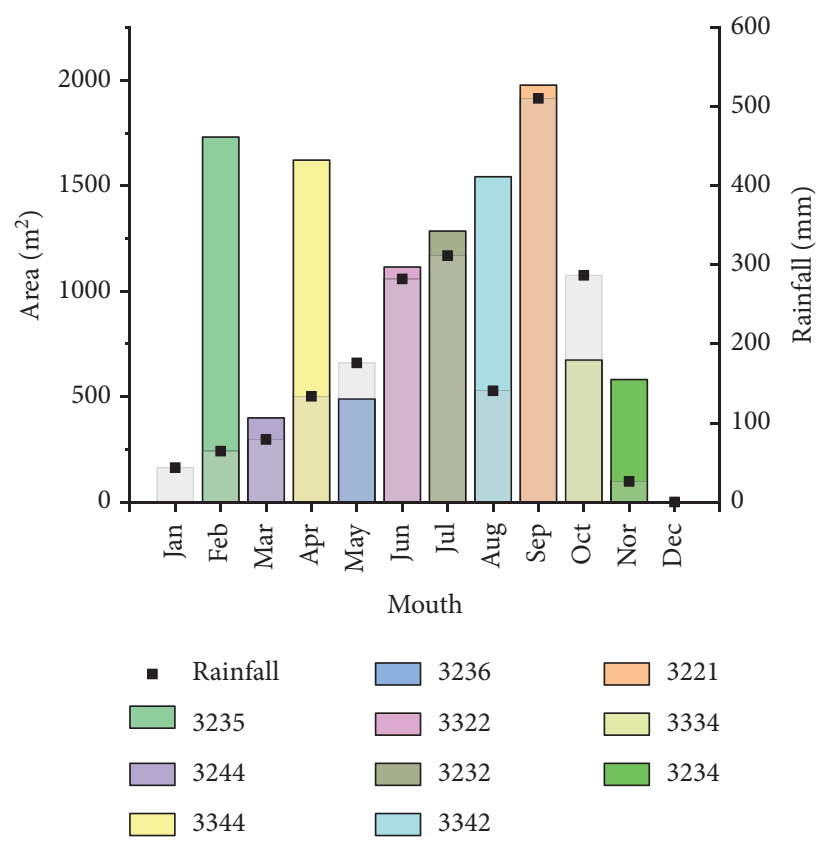

Figure 23: Diagram of the area of active characteristic zone concerning the total superposed displacement.

right rear of the bank slope and featured by high slope and the young stage was the vertical displacement prone area and formed a $10 \mathrm{~m}$ buffer zone; when the rainfall decreased from $26 \mathrm{~mm}$ to $0 \mathrm{~mm}$, its area change was $2593.59 \mathrm{~m}^{2}$ with an area changing rate of $80.4 \%$.

1.9.3. Analysis of Total Toppling Evolution. Similarly, under the condition of different rainfalls, the total displacement nephogram was classified into three grades using the Jenks best natural break method [41-48]: weak total deformation zone where the total displacement is smaller than $11.68 \mathrm{~mm}$ is represented by 1 ; medium total deformation zone where the total displacement ranges from $11.69 \mathrm{~mm}$ to $18.13 \mathrm{~mm}$ is represented by 2 ; strong total deformation zone where the total displacement is greater than $27.33 \mathrm{~mm}$ is represented by 3 . Based on the geometrical partition (Figure 6) and geometric features, the evolution nephogram of the total 
displacement was obtained through the superposition of ArcGIS raster layers (Figure 21).

The strong deformation zones of superposed total displacement can be obtained through GIS in Figure 21. The influence of zones with a small area was ignored, the strong deformation zones with an area larger than $1000 \mathrm{~m}^{2}$ were counted, and the zones with an area change rate greater than $15 \%$ were selected. As shown in Figure 22, the area variation of strong deformation zones under different rainfalls is explored, and it can be seen that the area of every strong deformation zone increased with the rainfall amount and reached the maximum when the rainfall was peak value of $510.60 \mathrm{~mm}$ and then decreased. Zone 3344 holds the largest area of $3290 \mathrm{~m}^{2}$ and was featured by medium and high slope and mature stage and formed a $50 \mathrm{~m}$ buffer zone. As shown in Figure 23, when the rainfall decreased from $510.60 \mathrm{~mm}$ to $286.70 \mathrm{~mm}$, the area change of Zone 3221 located in the right front and left rear of bank slope and formed a $10 \mathrm{~m}$ buffer zone was $1977.56 \mathrm{~m}^{2}$ with an area changing rate of $98.26 \%$; it was featured by medium-high slope and young stage and was the total displacement prone area.

\section{Conclusions}

Based on discrete surface displacement monitoring data and different geological divisions, this paper explored the toppling deformation evolution law of each zone in a typical reverse-dip rock slope under the condition of different rainfalls; this research can provide some reference for monitoring, advance warning, and prevention of similar anti-inclined slopes. The main research results are as follows:

(1) Taking the bank slope, gully buffer zone, and erosion degree as the development characteristic factors, the bank slope is divided into 104 development characteristic zones, and the largest characteristic zone is featured by high slope and mature stage and forms a $10 \mathrm{~m}$ buffer zone.

(2) The horizontal displacement mainly occurs on the right front and middle rear of the bank slope while the vertical displacement mainly occurs on the middle of the bank slope; when the rainfall increases to the maximum, the toppling deformation reaches the peak; higher rainfall intensity increases the displacement while vertical displacement is more sensitive to the rainfall than horizontal displacement since the obvious vertical deformation area is $247417.77 \mathrm{~m}^{2}$ and accounts for $80.07 \%$ in flood season while obvious horizontal deformation area is $43083.64 \mathrm{~m}^{2}$ and accounts for $74.61 \%$.

(3) Under the influence of rainfall, the development characteristic partition is superimposed with the spatial and temporal evolution nephogram of toppling displacement. When the rainfall increases, the maximum area of displacement superposition strengthening deformation zone is $3290 \mathrm{~m}^{2}$, which is characterized by medium and high slope and mature stage and $50 \mathrm{~m}$ gully buffer zone. When the rainfall decreases, the area change of the most prone zone of displacement superposition in the horizontal direction is $2502.23 \mathrm{~m}^{2}$, with a change rate of $76.5 \%$, which is located in the middle and rear of the bank slope. The area change of the most prone zone of displacement superposition in the vertical direction is $2593.59 \mathrm{~m}^{2}$, with a change rate of $80.4 \%$, which is located at the right rear of the bank slope. The area change of the most prone zone of total displacement superposition is $1977.56 \mathrm{~m}^{2}$, and its change rate is $98.26 \%$, which is mainly located in the right front and left rear of the bank slope.

\section{Data Availability}

The processed data required to reproduce these findings cannot be shared at this time as the data also form part of an ongoing study.

\section{Conflicts of Interest}

The authors declare no conflicts of interest.

\section{Acknowledgments}

This project was supported by the National Natural Science Foundation of China (52068066 and 51908482) and the Scientific Research Program of the Higher Education Institution of Xinjiang (XJEDU2018Y008).

\section{References}

[1] R. Huang, "Large-scale landslides and their sliding mechanisms in China since the 20th century," Chinese Journal of Rock Mechanics and Engineering, vol. 26, pp. 433-454, 2007.

[2] R. Huang, "Geodynamical process and stability control of slope development," Chinese Journal of Rock Mechanics and Engineering, vol. 27, pp. 1525-1544, 2008.

[3] D. C. Wyllie, "Toppling rock slope failures examples of analysis and stabilization," Rock Mechanics Felsmechanik Mcanique des Roches, vol. 13, no. 2, pp. 89-98, 1980.

[4] S. L. Nichol, O. Hungr, and S. G. Evans, "Large-scale brittle and ductile toppling of rock slopes," Canadian Geotechnical Journal, vol. 39, no. 4, pp. 773-788, 2002.

[5] X. Tu, F. Dai, X. Lu, and H. Zhong, "Toppling and stabilization of the intake slope for the Fengtan Hydropower Station enlargement project, Mid-South China," Engineering Geology, vol. 91, no. 2-4, pp. 152-167, 2007.

[6] E. Eberhardt, "Twenty-ninth Canadian Geotechnical Colloquium: the role of advanced numerical methods and geotechnical field measurements in understanding complex deep-seated rock slope failure mechanisms," Canadian Geotechnical Journal, vol. 45, no. 4, pp. 484-510, 2008.

[7] Z. Zhang, G. Liu, S. Wu et al., "Rock slope deformation mechanism in the cihaxia hydropower station, northwest China," Bulletin of Engineering Geology and the Environment, vol. 74, no. 3, pp. 943-958, 2014.

[8] M. Liu, F.-z. Liu, R.-q. Huang, and X.-j. Pei, "Deep-seated large-scale toppling failure in metamorphic rocks: a case study of the Erguxi slope in southwest China," Journal of Mountain Science, vol. 13, no. 12, pp. 2094-2110, 2016.

[9] L. Xie, E. Yan, J. Wang, G. Lu, and G. Yu, "Study on evolutionary characteristics of toppling deformation of reverse-dip 
layered rock slope based on surface displacement monitoring data," Environmental Earth Sciences, vol. 77, no. 4, 2018.

[10] J.-c. Cai, N.-p. Ju, R.-q. Huang et al., "Mechanism of toppling and deformation in hard rock slope: a case of bank slope of Hydropower Station, Qinghai Province, China," Journal of Mountain Science, vol. 16, no. 4, pp. 924-934, 2019.

[11] S. Gschwind, S. Loew, and A. Wolter, "Multi-stage structural and kinematic analysis of a retrogressive rock slope instability complex (Preonzo, Switzerland)," Engineering Geology, vol. 252, pp. 27-42, 2019.

[12] S. Sardana, A. K. Verma, R. Verma, and T. N. Singh, "Rock slope stability along road cut of Kulikawn to Saikhamakawn of Aizawl, Mizoram, India," Natural Hazards, vol. 99, no. 2, pp. 753-767, 2019.

[13] D. Shaunik and M. Singh, "Bearing capacity of foundations on rock slopes intersected by non-persistent discontinuity," International Journal of Mining Science and Technology, vol. 30, no. 5, pp. 669-674, 2020.

[14] N. Caine, "Toppling failures from alpine cliffs on ben Lomond, Tasmania," Earth Surface Processes and Landforms, vol. 7, no. 2, pp. 133-152, 1982.

[15] R. E. Goodman and J. W. Bray, "Toppling of rock slopes, specialty conference on rock engineering for foundations and slopes," Engineering, vol. 8, 1976.

[16] L. R. Alejano, I. Gómez-Márquez, and R. Martínez-Alegría, "Analysis of a complex toppling-circular slope failure," Engineering Geology, vol. 114, no. 1-2, pp. 93-104, 2010.

[17] R. Huang, L. Yusheng, and Y. Ming, "The implication and evaluation of topping failure in engineering geology practice," Journal of Engineering Geology, vol. 25, pp. 1165-1181, 2017.

[18] D. P. Adhikary and A. V. Dyskin, "Modelling of progressive and instantaneous failures of foliated rock slopes," Rock Mechanics and Rock Engineering, vol. 40, no. 4, pp. 349-362, 2007.

[19] M. Amini, A. Majdi, and M. A. Veshadi, "Stability analysis of rock slopes against block-flexure toppling failure," Rock Mechanics and Rock Engineering, vol. 45, no. 4, pp. 519-532, 2012.

[20] A. Majdi and M. Amini, "Analysis of geo-structural defects in flexural toppling failure," International Journal of Rock Mechanics and Mining Sciences, vol. 48, no. 2, pp. 175-186, 2011.

[21] D. Roy and P. Maheshwari, "Probabilistic analysis of rock slopes against block toppling failure," Indian Geotechnical Journal, vol. 48, no. 3, pp. 484-497, 2017.

[22] D. Huang, D. Cen, G. Ma, and R. Huang, "Step-path failure of rock slopes with intermittent joints," Landslides, vol. 12, no. 5, pp. 911-926, 2014.

[23] J.-J. Lian, Q. Li, X.-F. Deng, G.-F. Zhao, and Z.-Y. Chen, “A numerical study on toppling failure of a jointed rock slope by using the distinct lattice spring model," Rock Mechanics and Rock Engineering, vol. 51, no. 2, pp. 513-530, 2017.

[24] P. Sikora and M. Wesołowski, "Numerical assessment of the influence of former mining activities and plasticity of rock mass on deformations of terrain surface," International Journal of Mining Science and Technology, vol. 31, no. 2, pp. 209-214, 2021.

[25] Z. Chen, W. Gong, G. Ma et al., "Comparisons between centrifuge and numerical modeling results for slope toppling failure," Science China Technological Sciences, vol. 58, no. 9, pp. 1497-1508, 2015.

[26] W.-C. Huang, K.-C. Li, J.-Y. Hsieh, M.-C. Weng, and W.-Y. Hung, "Deformation behaviors of dip slopes considering the scale effect and their geological properties," Bulletin of Engineering Geology and the Environment, vol. 79, no. 3, pp. 1605-1617, 2019.

[27] Z. Tao, Y. Shu, X. Yang, Y. Peng, Q. Chen, and H. Zhang, "Physical model test study on shear strength characteristics of slope sliding surface in Nanfen open-pit mine," International Journal of Mining Science and Technology, vol. 30, no. 3, pp. 421-429, 2020.

[28] Y. Ye, Z. Guangcheng, C. Hongjie, W. Mingfei, B. Liulei, and C. Zheng, "Study on the failure mechanism of rock slope with layered cataclastic structure," Chinese Journal of Rock Mechanics and Engineering, vol. 40, pp. 365-381, 2021.

[29] D. P. Adhikary, A. V. Dyskin, R. J. Jewell, and D. P. Stewart, "A study of the mechanism of flexural toppling failure of rock slopes," Rock Mechanics and Rock Engineering, vol. 30, no. 2, pp. 75-93, 1997.

[30] M.-A. Brideau and D. Stead, "Controls on block toppling using a three-dimensional distinct element approach," Rock Mechanics and Rock Engineering, vol. 43, no. 3, pp. 241-260, 2010.

[31] A. K. Alzo'ubi, C. D. Martin, and D. M. Cruden, "Influence of tensile strength on toppling failure in centrifuge tests," International Journal of Rock Mechanics and Mining Sciences, vol. 47, no. 6, pp. 974-982, 2010.

[32] D. Gu and D. Huang, "A complex rock topple-rock slide failure of an anaclinal rock slope in the Wu Gorge, Yangtze River, China," Engineering Geology, vol. 208, pp. 165-180, 2016.

[33] D. Huang and D. M. Gu, "Influence of filling-drawdown cycles of the Three Gorges reservoir on deformation and failure behaviors of anaclinal rock slopes in the Wu Gorge," Geomorphology, vol. 295, pp. 489-506, 2017.

[34] S. Yu, X. Ren, J. Zhang, H. Wang, and Z. Sun, “An improved form of smoothed particle hydrodynamics method for crack propagation simulation applied in rock mechanics," International Journal of Mining Science and Technology, vol. 31, no. 3, pp. 421-428, 2021.

[35] N. Bar, M. Kostadinovski, M. Tucker et al., "Rapid and robust slope failure appraisal using aerial photogrammetry and 3D slope stability models," International Journal of Mining Science and Technology, vol. 30, no. 5, pp. 651-658, 2020.

[36] M. Dong, F. Zhang, J. Lv, Y. Fei, and Z. Li, "Study of stability influencing factors of excavated anti-dip rock slope," KSCE Journal of Civil Engineering, vol. 24, no. 8, pp. 2293-2303, 2020.

[37] Z.-y. Wang, D.-m. Gu, and W.-g. Zhang, "Influence of excavation schemes on slope stability: a DEM study," Journal of Mountain Science, vol. 17, no. 6, pp. 1509-1522, 2020.

[38] A. N. Strahler, "Hypsometric (Area-Altitude) analysis of erosional topography," The Geological Society of America Bulletin, vol. 63, 1952.

[39] W. M. Davis, The Geographical Cycle, Macmillan Education, UK, 1973.

[40] J. Chen, S. T. Yang, H. W. Li, B. Zhang, and J. R. Lv, "Research on geographical environment unit division based on the method of natural breaks (Jenks)," The International Archives of the Photogrammetry, Remote Sensing and Spatial Information Sciences, vol. XL-4/W3, pp. 47-50, 2013.

[41] Z. Leng, Y. Fan, Q. Gao, and Y. Hu, "Evaluation and optimization of blasting approaches to reducing oversize boulders and toes in open-pit mine," International Journal of Mining Science and Technology, vol. 30, no. 3, pp. 373-380, 2020.

[42] I. Vennes, H. Mitri, D. R. Chinnasane, and M. Yao, "Largescale destress blasting for seismicity control in hard rock 
mines: a case study," International Journal of Mining Science and Technology, vol. 30, no. 2, pp. 141-149, 2020.

[43] A. I. Lawal, S. Kwon, O. S. Hammed, and M. A. Idris, "Blastinduced ground vibration prediction in granite quarries: an application of gene expression programming, ANFIS, and sine cosine algorithm optimized ANN," International Journal of Mining Science and Technology, vol. 31, no. 2, pp. 265-277, 2021.

[44] X. Liu, S. Song, Y. Tan et al., "Similar simulation study on the deformation and failure of surrounding rock of a large section chamber group under dynamic loading," International Journal of Mining Science and Technology, vol. 31, no. 3, pp. 495-505, 2021.

[45] R. Kumar, P. K. Mandal, A. Narayan, and A. J. Das, "Evaluation of load transfer mechanism under axial loads in a novel coupler of dual height rock bolts," International Journal of Mining Science and Technology, vol. 31, no. 2, pp. 225-232, 2021.

[46] Y. Zhou, D. Zhao, B. Li, H. Wang, Q. Tang, and Z. Zhang, "Fatigue damage mechanism and deformation behaviour of granite under ultrahigh-frequency cyclic loading conditions," Rock Mechanics and Rock Engineering, vol. 54, no. 9, pp. 4723-4739, 2021.

[47] J. Ma, X. L. Li, J. G. Wang et al., "Experimental study on vibration reduction technology of hole-by-hole presplitting blasting," Geofluids, vol. 20, 2021.

[48] J. Wang, T. Zuo, X. Li, Z. Tao, and J. Ma, "Study on the fractal characteristics of the pomegranate biotite schist under impact loading," Geofluids, vol. 22, 2021. 